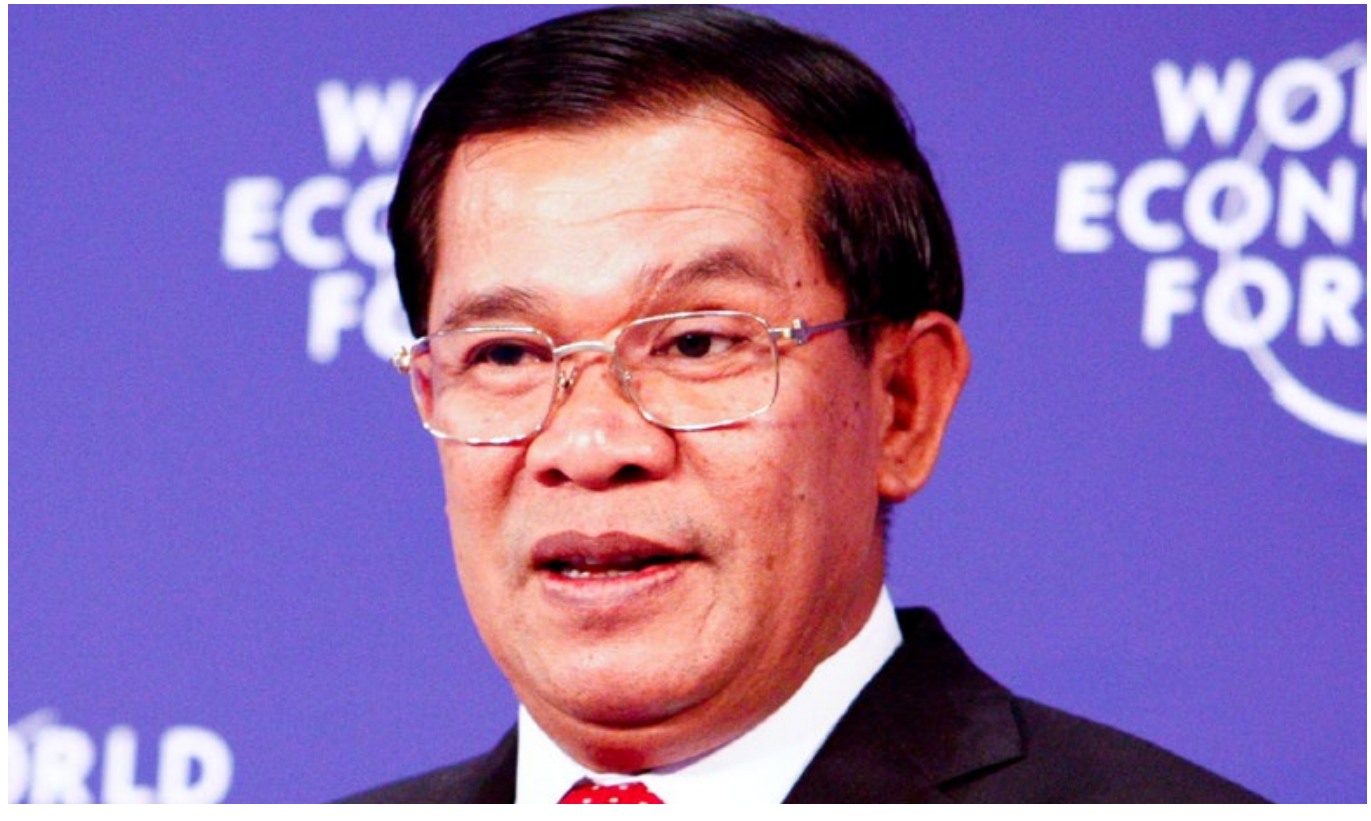

'Hun Sen Won't Die, Workers Will Die'

\section{The Geopolitics of Labour in the Cambodian Crackdown}

\title{
Sabina LAWRENIUK
}

Over the past year, the Cambodian government has engaged in a full-frontal assault on freedoms of expression, association, and assembly. The latest development has seen Cambodia effectively becoming a one-party state, after the ruling party swept all 125 seats on offer in the National Assembly at the polls held in July 2018. In this essay, Sabina Lawreniuk examines the ways in which both labour politics and China have played a role in these changes.
Cambodia's Prime Minister Hun Sen. PC: Wikimedia Commons. n September 2018, the European Parliament tabled a high-stakes debate on the aggravated human rights situation in Cambodia. Under threat was the continued inclusion of Cambodia in the European Union's Everything But Arms (EBA) trade scheme. The EBA agreement-introduced by the EU in 2010 to promote economic growth in the world's Least Developed Countries-grants Cambodia and 48 other beneficiary states tariff-free imports to the EU market, as the name suggests, on every product except arms and armaments. Yet this access comes with 
one, albeit significant, catch: a clause in the agreement binds beneficiaries to recognise and uphold fundamental human and labour rights conventions.

It is not hard to parse where the Cambodian government has fallen foul of this requirement over the last 12 months. Rather, it is more difficult to accurately convey the intensity of the government's full-frontal assault on freedoms of expression, association, and assembly; a nuclear response to electoral decline in the 2017 local elections and the subsequent fear of losing power in national elections in 2018. Encompassing the closure of newspapers and radio stations, dispersal of protests, and increased surveillance of civil society in public records and online, the so-called 'crackdown' peaked with the imprisonment of the main opposition party leader, Kem Sokha, before the ultimate dissolution of the opposition party itself at the behest of Cambodia's injudiciously partial Supreme Court. Without a credible opponent on ballots, the government swept to victory at the national polls held in July 2018; its 77 percent share of the vote delivering an unprecedented clean sweep of all 125 seats on offer in the National Assembly.

\section{Nothing New under the Sky}

'Descent into outright dictatorship', screamed the Cambodia Daily's headline on the morning of 4 September 2017, when news broke of Sokha's arrest. The sentiment, if not strictly hyperbolic, was somewhat disingenuous. Cambodia's democratic credentials have not been recently shed. Instead, they have been long stretched by a government brought to power in a bloody 1997 coup and a leader who selfidentifies as the 'strongman of strongmen'the sixth-longest serving non-royal head of state in the world. For many years, however, Cambodia's rulers have had to take care to mask the autocratic tendencies of their tenure; the nation's economic dependency on aid and then preferential trade, like the EBA, rendering the government beholden to maintain at least a façade of liberal progress to satiate the 'good governance' strings that come attached.

There is little chance that the EU's watchdogs have, until now, simply missed the evidence of a deeper malaise. The red flags signalling a democratic deficit have always been prominent: from the long-standing harassment, detention, and assassination of peaceful human rights defenders like Chea Vichea, Chut Wutty, and Tep Vanny, to ratcheting up efforts to deter civil society organisation through dubious, hostile legislation. More likely, the trade-offs between popular power and stability have been weighed by the EU and accepted, where these have tipped in its favour-in this case, shoring up a regional ally and trading partner, as well as delivering rapid rates of economic growth that have won Cambodia middle-income status, thus serving up a ready exemplar of neoliberal development logic.

Here, the electoral cycle has been the historic rhythm to which the waxing and waning of Cambodia's democratic aspirations and aspersions have been pegged. The government's control has tended to tighten during election season, only to cede once results have been returned. In this way, the leadership has managed to tread a path between its benefactors' demands for liberal development and its own concern for the continued restitution of its command. Indeed, with the 2018 election now out of the way, there have already been signs of a return to Cambodia's own brand of normalcy. Sokha and other political prisoners like Tep Vanny have been released, if under unusual license: Vanny, having had her original conviction overturned by royal pardon, has been handed down a new suspended sentence for earlier charges; Sokha remains under house arrest, confined to the few streets around his home in the capital.

However, for many commentators these reversals signal the onset of a customary softening of the government's stance in the post-election setting. Significantly, among their number appears to be the EU, whose 
response has been a mirroring of this relaxation of attitude. At the time of writing (September 2018), the threat of withdrawal of the EBA looks to have been rescinded. In its final resolution, passed on 13 September, the EU Parliament watered down its assertive rebuke of the Cambodian government's actions. While reiterating calls for the immediate and full release of Kem Sokha and reinstatement of his party, strongly worded sentiment denouncing 'sham elections' and an 'illegitimate government' that appeared in an early draft motion was diluted to 'concerns over conduct' and 'credible process' in the accepted edit; the proposition of a broad response, like suspension of the EBA, became targeted sanctions aimed at individuals responsible for the most serious abuses of rights.

Plus ça change, then, has been the response in some circles, as the always uneven, sometimes uneasy, yet timeworn truce between the two sides, Cambodia and the EU, appears to have been reinstated. Nevertheless, there are indications beneath the banality of surface impressions that the balance of power has significantly shifted. For one thing, from the Cambodian side this return to normalcy has been accepted with nothing akin to the good grace of old. Instead, the Cambodian government's inclination to regard its admonition with hostility rather than humility has been markedly evident. 'Hun Sen won't die, workers will die,' the Prime Minister himself has warned icily whenever the menace of sanctions like the revocation of EBA looms. A government statement decried the September resolution as 'biased', 'reckless', and 'insensitive'.

\section{Wooing the Workers}

There is a fundamental truth to Hun Sen's words. His party's focus on garment workers throughout the recent electoral campaign is, perhaps, a sign of the government steeling itself for impact. Indeed, the garment sector, whose rapid expansion over the past two decades has been the ballast of Cambodia's booming economy, is heavily reliant on the $\mathrm{EU}$ market, with almost 50 percent of Cambodia's exports of clothing and footwear heading there in 2017 (ILO 2018). The loss of the EBA would represent a significant threat to the viability of a sector where for buyers, as manufacturers know, the bottom line is always the bottom line. The imposition of tariffs would cost the sector somewhere in the region of 700 million USD, risking the flight of investors and thus placing the 800,000 jobs in the industry in jeopardy.

The government's concerted overtures to garment workers since last summer-increased wages, improved social security benefits, and personal audiences with the Prime Ministerare, in part, a response to this threat: an effort to forge new alliances between the ruling party and a group which, though sizeable, it has typically ignored in its electioneering-concentrating instead on its traditional bedrock of support in rural areas. Yet this favourable attention also serves as early insurance against any potential fallout from the EU's actions. Indeed, while making these efforts to win esteem among garment workers, the Cambodian government has also pushed a preemptive narrative that links any punitive reprisals from the EU to the backstage meddling of exiled opposition leader Sam Rainsy, now based in Paris. The latest statement on the EU's September resolution, for example, acerbically references 'a notorious opposition figure' in its opening paragraph, and goes on to frame Rainsy as having an active role in the EU's process, claiming that 'this resolution was finalised with his assent' (Mission of the Kingdom of Cambodia to the European Union 2018).

The promotion of this narrative is also aimed at decoupling the traditional links between Sokha and Rainsy's party-the Cambodia National Rescue Party (CNRP)-and workers, who have been a strong base of support for the opposition. The political crisis that broke in 2013, though it had the opposition leadership as its figurehead, was fuelled by the rising discontent of workers, when a general strike 
called in the wake of a disputed election brought not tens, but hundreds of thousands of people on to the streets and the government almost to its knees. Alongside its softer appeals for the favour of workers, it is this kind of uprising that the government has sought to prevent through a concomitant punitive regime targeting the trade union movement. A new, draconian Trade Union Law passed in 2016 has all but paralysed many once-vibrant organisations. A mix of half-baked clauses and unachievable conditions, characteristic of Cambodia's preference for rule by, rather than of, law have made it hard if not impossible for many local branches to fulfil the criteria to formally reregister with the Ministry of Labour, as required. Instead, their operations are left in a precarious grey area of the law. Many leaders are now too frightened of the threat of carceral penalties to join their members on the picket line.

Yet the government patronises and dangerously underestimates workers if it believes that this unrest is whipped up only by the actions of trade union bosses and opposition leaders, and that by dispensing with the latter the concerns of the former will simply go away. Two decades of stagnating and declining wages are intuitively sensed by workers in their stalled livelihoods and waylaid aspirations of improved living conditions and life chances. Banning protests and curtailing unions addresses the symptoms but not the cause of Cambodia's recent wave of disquiet, which underneath this rough dressing of calm is otherwise left to fester.

\section{Warming Up to China}

It is the increasing inability of the Cambodian government to manage the rising discontent of workers within the strictures of its donordirected liberal façade that underlies, at least in part, Cambodia's significant geopolitical manoeuvres of recent years. Worker consent, happiness, and democratic acquiescence to the current regime's rule has proved incompatible with its ruthlessly exploitative brand of neoliberal crony capitalism, where the continued impoverishment of those at the bottom is driving the massed wealth of a few at the top. The killing of five striking workers by military police during the 2013 unrest shows just how thin this veneer of liberal propriety has been stretched.

Accordingly, the Cambodian government has warmed of late to China's advances in the region, a key node in the Chinese Belt and Road Initiative. China's financing and loans come with their own strings attached, accused by some of being 'debt trap diplomacy'-the perils of which countries like Sri Lanka have become all too aware of in recent months (AbiHabib 2018). Yet, despite the risks, China does provide a ready supply of funds with a 'don't ask, don't tell' approach to internal affairs. The allure of this interested apathy has proved hard to resist among Cambodia's leaders, looking to leverage against EU dictates. Today, 70 percent of Cambodia's 4.3 USD billion in bilateral debt is owed to China, whose share eclipses even that of multilateral lenders like the International Monetary Fund and World Bank. Since 2013, China has also been Cambodia's largest foreign direct investor, ploughing in an average of 1 billion USD annually, surpassing Cambodia itself in 2016 as the leading source of investment capital in the country.

It is the weight of this new backing, beyond previous Western dependencies, that has allowed the Cambodian government to be so bullish of late in its home and foreign policy response, without fearing the consequences of highlighting the EU's shallow and often hypocritical stance. The EU's wavering resolve in tackling the crisis in Cambodia likely stems, too, from its worries about strengthening the bond between Cambodia and China, which would weaken its own influence further. Alas, as Hun Sen astutely notes, Cambodia's new win-win is likely lose-lose for workers in any eventuality. Their livelihoods are at stake whether the EU intervenes or abandons them to global industry's race to the bottom. 
This text is taken from Dog Days: A Year of Chinese Labour, Civil Society, and Rights, Made in China Yearbook 2018, edited by Ivan Franceschini and Nicholas Loubere, published 2019 by ANU Press, The Australian National University, Canberra, Australia.

doi.org/10.22459/MIC.04.2019.37 